\title{
Creative Economy-Based Da'wah Approach: in the Deaf Community in Lampung
}

\author{
Aliyah Mantik ${ }^{*}$, Khomsahrial Romli ${ }^{2}$, Fitri Yanti ${ }^{3} \&$ Fauzi $^{4}$ \\ ${ }^{1234}$ Raden Intan Islamic State University Lampung, Indonesia \\ *mantikaliyab@gmail.com
}

\begin{abstract}
This study aims to describe the empowerment-based da'wah approach among the deaf in the Lampung region. This research also identifies the elements of persuasive da'wah in the process of the empowerment process. This study used a descriptive qualitative method by collecting data through interviews and observations and searching literature sources that were considered relevant. The results showed that empowerment has two functions, first as an instrument to build economic independence, which is carried out through providing skills based on hobby development. Secondly, empowerment becomes a persuasive da'wah instrument. The process of preaching uses sign language with an orientation to change the dimensions of religiosity, so that there is a change in understanding, experience and appreciation of religion towards a positive direction and an increase in the confidence of members of the deaf community.
\end{abstract}

Keywords; da'wah approach; deaf; creative economy.

\section{ABSTRAK}

Penelitian ini bertujuan mendeskripsikan pendekatan dakwah berbasis pemberdayaan pada kalangan tunarungu di wilayah Lampung. Penelitian ini juga sekaligus mengidentifikasi unsur-unsur dakwah persuasif dalam proses pemberdayaan yang dimaksud. Penelitian ini menggunakan metode kualitatif deskriptif dengan mengumpulkan data melalui wawancara dan observasi serta penelusuran sumber pustaka yang dipandang relevan. Hasil penelitian menunjukkan pemberdayaan memiliki dua fungsi: pertama sebagai instrumen membangun kemandirian ekonomi, yang dilakukan melalui pembekalan keterampilan berbasis pengembangan hobi. Kedua pemberdayaan menjadi instrumen dakwah persuasif. Proses dakwah menggunakan bahasa isyarat dengan orientasi perubahan dimensi-dimensi religiusitas, sehingga terjadi perubahan pemahaman, pengalaman dan penghayatan kegamaan kearah positif dan peningkatan rasa percaya diri para anggota komunitas tunarungu.

Kata-kata kunci; Pendekatan da'wah; tunarungu; ekonomi kreatif. 


\section{INTRODUCTION}

Unemployment rate in Indonesia is still relatively high. This is correlated with still narrow employment opportunities. Job opportunities are not able to accommodate school and university graduates maximally. As a result, both open and hidden unemployment rates are still high. The unemployment rate in Indonesia has fluctuated, along with government programs that have also undergone changes in reducing the unemployment rate (Kurniasari et al., 2020; Mahmudah, 2018). One of the groups that is vulnerable to not finding work and becoming unemployed is disability, including the deaf. Most of them become unemployed and only depend on their parents and family for their livelihood (Amalia, 2019; Sarry, 2018).

So far, there have been many approaches and paradigms that are not right on target in implementing development programs. One of them is relying too heavily on natural wealth, in the form of oil and gas or mining and energy. In fact, many of the approaches that focus on oil and gas and other assets have failed (Hidayaturrahman, 2018). Many development programs run by the government have failed. There are many factors that cause the failure of the development and empowerment programs carried out by the government, so the results are not clear (Hidayaturrahman et al., 2020).

Rehabilitation centers for persons with disabilities are already available in several cities in Indonesia however, the programs implemented by the central government or local governments are still less successful, not yet representing the voices of children with hearing disabilities. Less successful can be seen from the understanding and behavior change of children with hearing disabilities after participating in organized programs or empowerment activities, deaf group still have difficulty understanding what is actually they do (Azizah, 2010). The deaf group was still confused after participating in these activities. Programs for deaf children with disabilities were not well targeted and failed. The failure referred to in this case is that community empowerment is carried out not as expected and the objectives of the empowerment carried out are not achieved (Muslim, 2017).

Prior to this research, there had been research that discussed the empowerment of the creative economy. As was done by Linzzy Pratami Putri and her friends, who conducted research on the empowerment of housewives in North Sumatra through creative economy training (Putri et al., 2019). In addition, there is another study conducted by Roza Linda who 
conducted creative economy research on waste processing in Pekanbaru, Riau (Linda, 2018). Dharma Setyawan also conducted research on empowerment through creative economy on tourism development in Lampung (Setyawan, 2017). As for the research on deafness that has been conducted discussing related to education, including that conducted by Sri Sulastri and Roko Patria Jati, who researched Islamic religious education for deaf students in Salatiga, Central Java (Sulastri \& Jati, 2016). Likewise, research conducted by Tomy Syafrudin and Sujarwo Sujarwo discussed mathematics learning materials for deaf students (Syafrudin \& Sujarwo, 2019). In addition, Rakhmad Fitriawan conducted research on deaf screen printing training activities in Yogyakarta (Fitriawan, 2016).

The article from this study aims to find out how the da'wah approach through creative economic empowerment can be a means of communication and an entry point for approaching deaf groups to foster religious aspects both in terms of religious understanding and practice of reading the Qur'an for ritual worship, as well as their economic empowerment.

This article has benefits for ustadz, preachers, religious leaders, religious organizations, that the approach to da'wah varies, not always through religious activities, it could be through creative economic empowerment activities, which is a necessity, that da'wah to deaf groups has complex challenges, not only from how to approach them, but also how to teach them, with their limitations, which are not the same as the object of da'wah in general.

This article uses a descriptive qualitative method, by collecting data through in-depth interviews with various informants consisting of members of the Pringsewu Deaf Community, Lampung who have attended training and economic empowerment creative. Interviews were also conducted with sign language interpreters, members of Lampung's disability friends, members of the Indonesian deaf welfare movement, and parents of deaf children. Data collection is also done by observation. Researchers made direct observations, interacted with deaf people in creative economic business activities, and carried out daily activities in competitions and religions. Researchers also observed firsthand the behavior and actions that are usually carried out by deaf people as well as da'wah activities that involve them.

Document searches were also carried out to complement references in various mass media and journals related to deaf discussion, economic 
empowerment and da'wah related to strategies and communication of the da'wah performed by ustadz, preacher and religious leaders. This research uses Kenneth E. Andersen's theory of persuasive communication.

\section{RESULT AND DISCUSSION}

\section{Creative Economy Empowerment; From Hobby to Independent}

Humans are always required to be adaptive to life, the goal is that humans always have the opportunity to exist and develop their lives. One of the efforts to increase the ability of individuals to adapt to the demands of life, including empowerment programs. In the process, empowerment is oriented towards increasing the power of individuals or groups to be able to compete with other individuals or groups (Koeswantono, 2017). The concept of empowerment is closely related to independence and participation, it departs from the view that community development is born from the ability of each individual supported by a spirit of participation and collaboration.

In Sumodiningrat's notes (Kurniawati, 2013), empowerment that takes place does not only focus on capacity development, empowerment must also cover three important aspects; firstly, building a conducive climate for the development of potential community (enabling). In other words, good empowerment must be directly proportional to environmental conducivity. Second, optimization of potential and independence (empowering). that is, individual abilities are expected to be identified and further developed according to their expertise or interest. Third, provide a guarantee of protection (protecting). Finally, empowerment is also expected to be able to provide assurance in the form of comprehensive assistance, both the certainty of getting a conducive environment and increasing independence.

The empowerment in question can be very specific, depending on the subject and the abilities to be improved, for example empowering the creative economy for deaf people. Through empowerment based on creative economy, children with hearing impairment are expected to be able to realize their advantages as a fun thing. With guidance, mentoring and empowerment, strengths through talents and interests can be developed into skills that are capable of producing work. this work can generate income to meet the daily needs of deaf children. .various empowerment efforts and activities carried out on deaf children in 
Lampung. The empowerment activities carried out are based on hobbies and tendencies.

First, one of the empowerment activities given to deaf children is with talent and interest in drawing or painting. Beni has also carried out many processes of interaction and communication with other deaf/ normal children. Because Beni has participated in many painting or drawing competitions held by the government, universities and those held by the private sector, as stated by Beni when interviewed by the researchers as follows: "I really like painting but in the past every time I draw I am embarrassed when people see it. But after participating in an activity with listening friends, being invited to take part in a painting competition and winning, I was happy and excited to draw. by drawing and participating in competitions I also earn money." (Interview Beni Pujiono, a member of the Pringsewu Tuli Community, at his home, 17 June 2019).

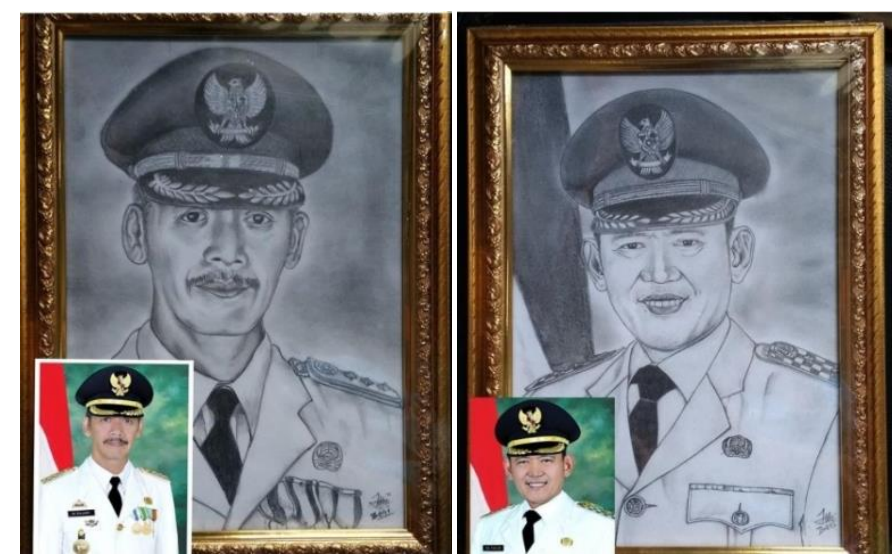

Source: Observation data, January 2019

Figure 1. Beni Pujiono's Painting Result.

Second, developing the potential of the deaf community through dance training activities. Dancing to a song is an activity that probably everyone can do. However, deaf children dance to music and have to follow the beat, which is very difficult to do. .To be able to listen to music and follow the beats of music, the five senses needed are the sense of hearing, while deaf children cannot hear any kind of sound. Constraints and lack of sensory functions owned by Revinda, a deaf child who from a young age likes dancing. Revinda who was born normal, because of an 
accident when she was a toddler, she had to lose her hearing and speech skills, did not prevent Revinda from continuing to do her fun dancing. Dancing for Revinda is not only to get rid of sadness, but by dancing and appearing in front of many people, Revinda can provide motivation for deaf children and other disabilities to always work and don't be ashamed of their shortcomings it has, because behind the shortcomings there must be advantages. "I became deaf when I was six years old, I rode a bicycle and I crashed, according to my parents, my ears bled and I couldn't hear anymore, after that I couldn't speak. I liked dancing since I was little. after I became a deaf child, I danced to forget my sadness. But after I joined an activity with my listening friends, I was happier, and it made my parents happy too." (Interview by Revinda, a member of the Pringsewu Deaf Community, at the studio, 17 May 2019).

Revinda is one of the deaf children who tries to always motivate children with hearing impairment and other disabilities to be able to work and try, so that they can become personally independent and economically independent without having to be ashamed and lamenting the fate of being deaf or disabled.

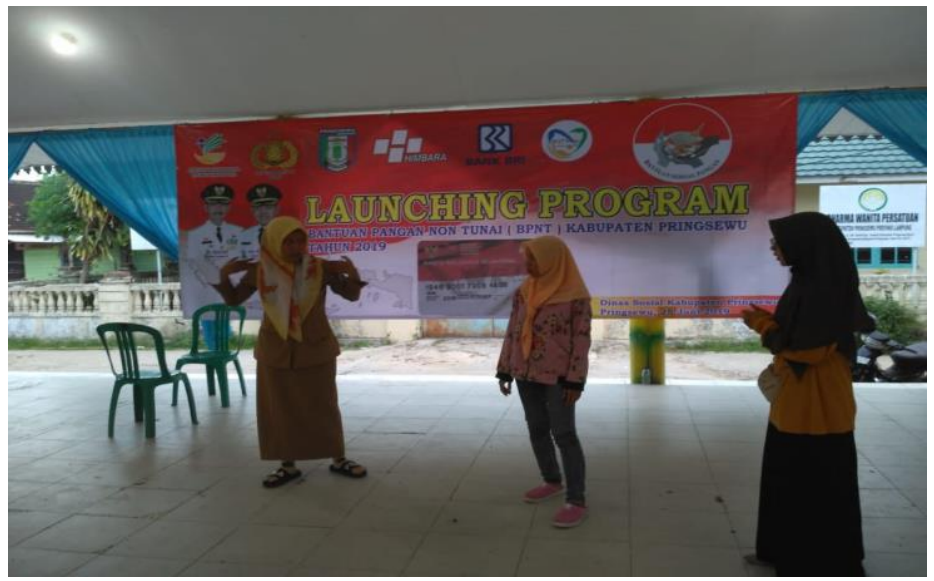

Source: Observation data, April 2019

Figure 2. Revinda prepares to appear at the opening of the launching of the non-cash food assistance program (BPNT) of the Pringsewu Regency Social Service, Lampung. 
Third, developing the potential of the deaf community, namely by training in "batik tulis". Deaf children also need a place where they can carry out interaction activities to communicate with others. By interacting and communicating, it will open a person's mind and develop, resulting in positive actions and activities. Batik is a skills program that is offered and is an activity for deaf children. Arum who participated in the batik skills activity admitted that she felt happy because she could learn to make batik and meet many people and get a job. By producing batik cloth, Arum can sell it and the money he gets can be used to meet his daily needs. "I am happy to be able to learn to write batik, rather than me at home and not doing anything, I prefer it here, here I have many friends, can chat and can make money to buy quota pulses and buy clothes. Every day I draw a batik pattern and give it a color, once a week I can produce batik cloth to make clothes." (Interview with Arum Dwi, a member of the Pringsewu Deaf Community, at the community office, 17 June 2019).

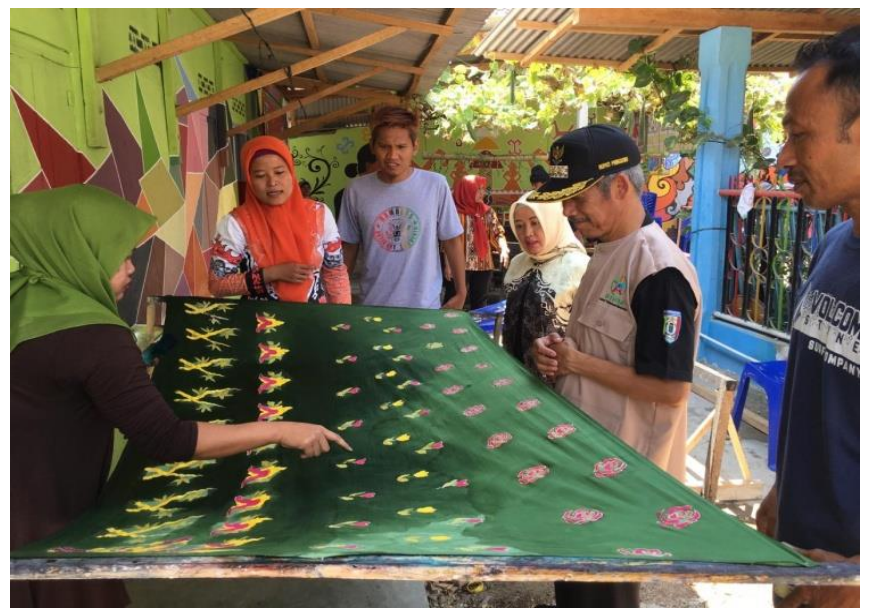

Source: Observation data, September 2019

Figure 3. Hand-written batik work by the deaf community attracted the attention of the Pringsewu Regent, Lampung.

Fourth, development of the creative economy to build the independence of the deaf, namely training in make-up and salon. Before participating in community empowerment for deaf children who already have extraordinary talents and interests. but with talents and interests 
alone, without assistance, children with hearing impairment will have difficulty developing their talents and strengths. In empowering an Islamic community based on a creative economy, deaf children are given direction and assistance to promote and market their work or creative economybased skills that they already have or have done. With the right empowerment strategy for and in accordance with children with hearing impairment, will make the results even more optimal.

Dressing up and grooming are activities that Caca or Cahyadi have enjoyed since childhood. By dressing up, Caca feels like she has found herself in a different form. caca who was born as a man, but due to the journey of life, lack of guidance and wrong relationships made Cahyadi metamorphose into a Caca. With the empowerment of Islamic communities based on the creative economy Caca can develop a wider community salon business and get more customers. "In the past, before I joined activities with listening friends, the only ones who came to my salon were deaf friends and my siblings. Maybe they are confused, because I am deaf. But now, I bave many customers. Yesterday there was an official's wife who came to hang her hair here, it's all because a friend heard about helping me promote." (Interview Caca, a member of the Pringsewu Deaf Community, at her salon, 17 May 2019).

Source: Observation data, February 2019

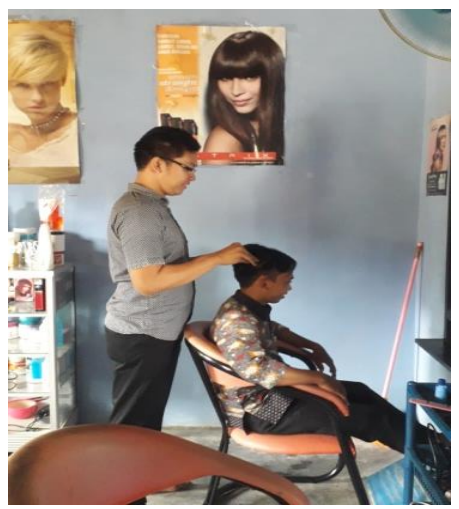

Figure 4. Salon practice results from the training of the deaf community.

Fifth, development of coffee mixing skills (barista). Barista skills take a long time, even now the process is still being done. Providing training in coffee-making skills (barista) is a very difficult thing, because it requires a lot of tools and accuracy in doing it. Deaf children do have better accuracy than normal children. However, deaf children have very limited knowledge 
about coffee tools and coffee names that come from various regions in Indonesia. The oral language comprehension of deaf children is also not as good as they can understand sign language. So that to carry out community empowerment involving deaf children must use a language they understand, namely sign language. And the empowerment process takes a long time. It is not easy to carry out community empowerment involving deaf misbalance. It takes time, planning and preparation so that community empowerment is carried out according to the desired goals. "It's hard for me to be able to memorize all the tools and all the ingredients for mixing coffee. Because sometimes what my listeners say in explaining I don't understand the language used. coupled with the many different names and types of coffee that I have to mix. Before I started selling, I learned how to mix coffee for about 4 months. I studied from morning to night with my listening friends." (Interview Ravi, a member of the Pringsewu Deaf Community, at a coffee shop, 17 June 2019).

The continuous mentoring process, skills training and the process of empowering the Islamic community based on creative economy, are expected to be a solution for the community, especially children with hearing disabilities who are able to develop their potential and be independent personally and economically independent.

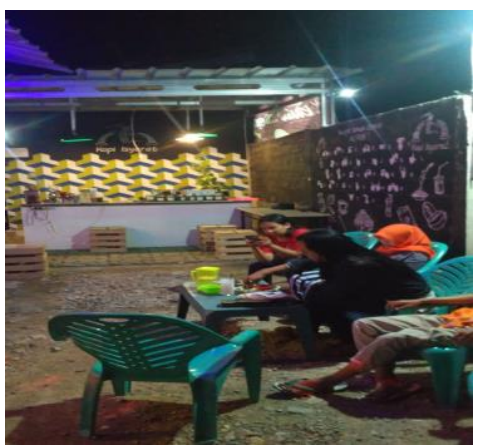

Source: Observation data, December 2019

Figure 5. The deaf serve coffee to buyers in coffee shop Isyarat.

In the picture above, several baristas are making coffee. There are still many obstacles in the process. Among the obstacles found were the process of memorizing the tools and ingredients for making coffee. Because sometimes it's difficult to find the right language, so it can't be understood. Besides that, there are many types of coffee that must be 
mixed, even the barista training activities have been going on for four months, but still some obstacles are found.

The continuous mentoring process, skills training and the process of empowering the Islamic community based on creative economy, are expected to be a solution for the community, especially children with hearing disabilities who are able to develop their potential and independent personally and economically independent. Based on observations, the following is the inventory data for the deaf community empowerment program participants, along with the abilities developed.

Table 1. Deaf, Talent and Skills.

\begin{tabular}{cccc}
$\begin{array}{c}\text { Deaf } \\
\text { Name }\end{array}$ & $\begin{array}{c}\text { Talent } \\
\text { Interest }\end{array}$ & $\begin{array}{c}\text { Name of } \\
\text { Trainer }\end{array}$ & $\begin{array}{c}\text { The place } \\
\text { of practice }\end{array}$ \\
\hline Beni Pujiono & Paint & Nafidah Sani, S.Pd & Residential house \\
Arum Dwi & Batik & $\begin{array}{c}\text { M. Rifa'i, S.Pd } \\
\text { Maratus Sholihah, } \\
\text { S.Pd } \\
\text { Revinda }\end{array}$ & $\begin{array}{c}\text { The house of batik } \\
\text { creations "Ramoners Art" } \\
\text { Pendopo Pringsewu }\end{array}$ \\
Cahyadi/Caca & Salon & $\begin{array}{c}\text { Yanto Salon } \\
\text { Kursus } \\
\text { Asih Wulandari, } \\
\text { S.Kom }\end{array}$ & Salon Yanto \\
& (Barista) & Residential house
\end{tabular}

Source: Data observation, September 2019

In the table above, it can be seen that there are six deaf members who are participants in the empowerment-based da'wah program. In order for the empowerment process to run well, each participant is guided by a companion. This illustrates that the deaf community empowerment process requires special attention, and cannot run instantly. Even so, the assistance provided is expected to be able to become social support for the deaf community so that they can build self-confidence.

According to Fatimah (Jarmitia, Sulistiani, \& Yulandari, 2016: 64), that what is meant by self-confidence is the accumulation of positive attitudes of an individual, in the form of a sense of being able to face situations or the environment. With the existence of such intensive assistance, it is hoped that the deaf community will get social support, 
which includes attention and empathy, information, encouragement to progress and appreciation.

\section{Empowerment as a Persuasive Da'wah Instrument}

Besides being empowered through various trainings, deaf children are also invited to take part in a series of activities that support community empowerment activities and creative economy-based skills by participating in competitions and attending events disabilities, events organized by the government and religious activities outside of existing skills training activities. They are given the opportunity to socialize and interact in the community. By socializing and interacting, it will generate new motivation and experiences, so that it will produce new innovations to be developed. Often deaf children are present in the community, making communication between deaf children and normal children also well established. Although initially between deaf children and normal children communicate only with symbols, the process will result in new interactions and communications.

Economic empowerment efforts carried out by the deaf community to other deaf people are also accompanied by religious da'wah activities. One of them is the effort made by the sign coffee shop in collaboration with the LAZ ABA Tahfidz Qur'an House, which is managed to pass young Al-Quran memorizers in Pringsewu Regency. Every Monday, Wednesday and Saturday after performing the Asar prayer in congregation at the mosque, they learn the Qur'an and memorize the Qur'an at the sign coffee shop. The activities of reciting and memorizing the Qur'an were indeed carried out by the students of Rumah Tahfidz, but with the holding of this collaboration, deaf children knew the hijaiyah letters and finally many ustadz, ulama and religious leaders knew where the child was deaf.

The deaf group actually has innovation and wants to change for the better. Deaf children also want to be able to know about religious teachings and be able to recite the Qur'an, but due to language limitations which result in limited information entering the understanding of deaf children. Coupled with, the unwillingness of human resources to support the desire of deaf children to be able to recite the Qur'an using sign language. The human resources referred to here are ustadz or ustadzah who specifically teach deaf children the Qur'an using sign language as long as this research was conducted there was not yet.

With empowerment through creative economy-based skills, they can be invited back to the nature of Islam. One of them was experienced by 
Caca or Cahyadi who returned to his natural state as a man. admitted by Caca or Cahyadi, so far there has been no guidance from parents (Caca's parents died when he was young, and Caca was cared for by his mother's siblings). He also got along wrong and made Cahyadi turn into Caca. Empowerment based on creative economy can help change the environment of deaf children who were not good enough to be much better. With assistance, skills training for children with hearing impairment can participate in activities that have good intentions and goals for them. Cahyadi's symptoms are important to pay attention to, because Cahyadi has a less conducive environment and tends to keep asking Cahyadi to abandon his male identity. however, as time goes by, Cahyadi begins to be able to give assertiveness and choose to continue life as its natural fit. This awareness was present, after Cahyadi studied religion a lot.

It is not easy to change someone's behavior. Must go through approaches, mentoring and coaching to be able to approach and change the behavior of deaf children. Da'wah activities through creative economic empowerment, can be an alternative to one of the problems of deaf children in terms of religion, namely making them believe and devoted to Allah SWT. As long as creative economic empowerment skills activities are carried out, deaf children are invited to perform congregational prayers at the mosque or at the location of the activity.

Not only invited to perform worship, but deaf people who are involved in the activities of the deaf community are also guided and given a good religious understanding, in accordance with Islamic guidance and teachings. Changes in economic ability and behavior by deaf children are appreciated by both parents and their families. Their parents think there are significant changes after participating in empowerment. For example, Beni, since he was a child, liked to draw, but has never been appreciated or sold, after joining the empowerment program Beni became more enthusiastic and spent more time at home to hone his skills. 
Table 2. Changes in the Behavior of Deaf Children Before and After Empowerment Based on Creative Economy.

\begin{tabular}{|c|c|c|}
\hline $\begin{array}{l}\text { Child } \\
\text { Deaf }\end{array}$ & $\begin{array}{c}\text { Before } \\
\text { Empowerment }\end{array}$ & $\begin{array}{c}\text { After } \\
\text { Empowerment }\end{array}$ \\
\hline Arum & $\begin{array}{l}\text { Not working, not diligent in } \\
\text { worshiping, depending on } \\
\text { parents, children who are angry } \\
\text { and less grateful. }\end{array}$ & $\begin{array}{l}\text { Already working, diligent in } \\
\text { worship, independent, the child } \\
\text { is full of enthusiasm and } \\
\text { motivates others. }\end{array}$ \\
\hline Beni & $\begin{array}{l}\text { Painting is just a hobby, not } \\
\text { praying diligently, often going to } \\
\text { play (traveling to the sea, to malls } \\
\text { and other entertainment venues). }\end{array}$ & $\begin{array}{l}\text { Painting makes money, pray } \\
\text { diligently, prefer to be at home } \\
\text { to draw or paint. }\end{array}$ \\
\hline Revinda & $\begin{array}{l}\text { Dancing to oneself, seldom } \\
\text { praying, grumpy, often going out } \\
\text { for games. }\end{array}$ & $\begin{array}{l}\text { Motivate other disabilities, pray } \\
\text { diligently, rarely get angry. }\end{array}$ \\
\hline Ravi & $\begin{array}{l}\text { Not knowing his talent, rarely } \\
\text { praying, spoiled, quiet and closed. }\end{array}$ & $\begin{array}{l}\text { Knowing his talents, praying } \\
\text { diligently, being independent, } \\
\text { being more open-minded. }\end{array}$ \\
\hline Caca & $\begin{array}{l}\text { Rarely pray, look like a woman, } \\
\text { do not know what is sin and what } \\
\text { is hell. }\end{array}$ & $\begin{array}{l}\text { Praying, wearing a male } \\
\text { appearance, knowing what is } \\
\text { sin and what is hell. }\end{array}$ \\
\hline
\end{tabular}

Source: Observation data and interview results, May 2020

Based on the table above, it can be identified that there is a change in religiosity in the deaf community. Religiosity itself is interpreted by Glock \& Stark (Mierrina, 2018) as a condition of the quality of individual religiosity which includes; the first dimension of belief such as aqidah and doctrine. Both dimensions of practice or dimensions of how a person practices sharia and religious rites. The three dimensions of appreciation, namely placing religion as a source of hope. the four dimensions of cognition, or how the individual understands the concept of belief that he embraces. The five dimensions of experience, or dimensions that show how individuals are able to display behavior or morals in accordance with their religious teachings.

Based on this theory, it can be concluded that the deaf community has experienced significant changes, especially in several dimensions. The first is the practical dimension, if previously members of the deaf empowerment participants rarely performed prayer activities, after joining the program they started practicing it. Second, there has been a change in the experience dimension, if previously some of the participants were irritable and showed aggressive attitudes, but after participating in the 
empowerment program, now they can socialize better. Third, there is also a change in the dimensions of cognition and appreciation. Now they can understand about the consequences of heaven and hell, so that this becomes an added value to their religious quality.

Empowerment of the Islamic community, especially deaf residents pay attention to unique characteristics, different from other normal children. So that in the process of implementing empowerment and coaching cannot be equated with the general public. Communication model suitable for deaf empowerment is persuasive communication. Persuasive communication according to Kenneth Andersen is a communication process that occurs between the communicator and the communicant by using certain symbols. the use of symbols is intended to influence the communicant, so that changes in the form of knowledge and behavior (Andersen \& Clevenger, 1963).

From Andersen's explanation, related to persuasive communication, there are several things that are relevant to the da'wah approach or da'wah communication carried out against deaf groups in Lampung.

First, the communication process. Communication is the process of conveying messages from communicators to communicants (Burns et al., 2003; Light \& McNaughton, 2014; Stevens, 1950). In empowerment activities for deaf children in Lampung, it involves intense communication, through persuasive communication. Persuasive communication has a changing effect on the deaf people who are the object of communication. Communication process with deaf groups in Lampung by providing skills training based on creative economy. Today's era of looking for a job is not that easy, especially for those with physical limitations. Not many companies accept deaf children as employees. Not because children with hearing impairment are unable to work, but there is also doubt that children with hearing impairment can work well, understand commands properly and correctly.

In addition to providing training, communication processes also take place in the form of providing business capital for deaf children. The deaf group also has the desire to open their own business with their own abilities. By providing business capital for the head of the deaf group, automatically giving them the opportunity to open a business independently. Next is to help the deaf group to market the products they produce. Market products and products of deaf groups by including them in activities outside of training activities, namely participating in 
competitions held by campuses, bazaar activities held by schools, and social activities held by the private sector or local government. The aim is to introduce products that the deaf group has produced and market their skills training results. In addition, they are also given lessons and understanding on how to market their work through social media, online media, print media and promotion from friends to friends.

The process of communication with the deaf group did take longer than the process of communicating and mentoring with other groups. The deaf group needs longer assistance, so that after being trained, assisted with business capital, assisted with marketing and so on, they also provide more intense assistance, when they are able to run a business. One of the weaknesses they have is that they get bored quickly with what they are doing, so assistance is needed so that they are more patient and diligent in running the creative economy business that has been initiated.

Assistance here is carried out continuously, meaning that even though children with hearing impairment already have skills and businesses based on creative economy, they must still be accompanied. Deaf children cannot be let go, because deaf children are still special children who must be accompanied and always directed. In the process of assisting them, the children are always motivated to always be enthusiastic and always inspired to encourage others.

The communication process also involved parents of the deaf group who felt happy and helped. So far, their parents feel alone in educating and fighting for the existence of a deaf group so that they are personally and economically independent. Now with the empowerment being carried out, parents of deaf groups feel that they are no longer alone in fighting for the fate of their children. They are very happy, if there are other people who care and pay attention to the deaf group, both from the aspect of economic empowerment and from the aspect of religion. At first the parents of the deaf group were hesitant, but in the end their parents believed, were happy and proud to see their child able to carry out creative economic empowerment activities, through their talents and interests, they were able generate income to meet their daily needs and make them independent individuals.

Second, communicator. Communicators or message givers in communication activities are actors who actively give messages to communicants or objects/ targets. Communicators have the aims and objectives of the communication activities carried out. Actors have the 
initiative in carrying out communication activities (Liu \& Priest, 2009; Revuelta, 2014; Watanabe et al., 2010). The actors in the communication for the empowerment of the deaf group are the Pringsewu Regency Government, the Pringsewu District Social Service, the Ramones Art creation house and the trainers of talent and interest skills who voluntarily provide skills training according to the talents and interests of children with hearing impairment.

Communicators or actors provide skills training according to the talents and interests of the deaf group. With the talents and interests that children with hearing impairment have, make them comfortable doing it, do not feel compelled to do empowerment activities and implement them until they are successful. The activities carried out by actors and communicators are varied and varied, ranging from various economic activities to various religious development activities.

Third, communicant. Communicant is the target/ object of communication activities. As an object, initially the communicant is a passive group, whose nature is waiting for what the actor does. But then the communicant can also be active in response to what the communicator is doing (Bretherton et al., 1981; Mehrabian \& Wiener, 1966; Ruddle et al., 2002). Communicants in the creative economy empowerment-based da'wah approach are deaf groups in Lampung. They become targets of actors, including government, religious leaders, and civil society groups in their efforts to empower their abilities based on the creative economy. Besides that, they are also the object/ target of preaching to foster and direct them to become religious, to worship better, in accordance with the demands and teachings of Islam.

Fourth, the use of symbols. Communication involves language, in general what is commonly used is verbal language. However, in certain instances, communication does not use verbal language but uses symbols. Symbols in communication represent verbal language. Symbols can be descriptions of verbal language that does not reach the recipient of the message. Symbols have the same important function as verbal language in communication (Loula et al., 2010; Mayer \& Musatti, 1992; Stephenson \& Linfoot, 1996).

Communicating with the deaf needs to pay attention to their specifics and basic needs. They cannot treat normal children the same. Normal children and deaf children have very prominent differences that must be observed carefully. The difference that really stands out and what really 
matters is language. Language is the most important factor in communication and interaction. with differences in the language used can hinder the communication process carried out.

Deaf groups often show asocial attitudes or withdraw from the environment. This situation is increasingly unfavorable, coupled with environmental attitudes or other pressures that come from outside him, his family and friends, in the form of ridicule, ridicule, and other similar forms of rejection. Deaf children often get unpleasant treatment in the environment and society. They are only seen as children with disabilities who have disadvantages, regardless of the advantages that children with hearing impairment have. This certainly makes deaf children even more insecure, uncertain, and doubtful about their existence. As an integral part of the listening society, deaf children cannot be separated from the prevailing social values and must be implemented.

To facilitate communication and interaction with deaf children, communication skills in sign language are needed. Each area for deaf children has its own dictionary of sign language or sign movements. By using and understanding sign language, deaf children will feel comfortable and have confidence in the activities carried out, so that the empowerment process based on the creative economy can be easily carried out.

The similarity of language in the communication used raises the comfort of the deaf. Feelings of comfort make it easier for them to follow the empowerment process based on the creative economy. the use of language different from the language they normally use, can create misunderstanding among the deaf. with the use of sign language (symbols) in the communication process, empowerment can run according to the plans and goals that have been made. most importantly and fundamentally, the deaf group understood only their own language, which was sign language.

Language is the initial capital of communication activities, which in turn result in interaction. If each party, the communicator with the communicant does not understand and understand the language used, then there is an error in meaning and an error in understanding will have an impact on other errors. Interactions that use symbols that can be understood can describe more than hundreds of words. With sign language, deaf children understand well all the commands and information conveyed.

Fifth, influence. Persuasive communication carried out by communicators has an influence on the communicant (Buchan et al., 2006; 
Michael et al., 2014; Ray \& Miller, 1991). Communication between the government, religious leaders, and civil society groups in Lampung with deaf groups has an impact that can be seen after communication occurs. Ongoing communication makes deaf children feel safe and comfortable in the same environment as them. As they feel they are in a community whose members are deaf children. They also feel they have something in common and feel valued, understood and understood what their wishes and hopes are trying to achieve.

Sixth, change. Communicators to communicate want to get a response from the communicant. The expected response varies. In persuasive communication, actors who communicate expect changes from the communicant or the object/ target (Damian et al., 2007; Hovland \& Weiss, 1951). The process of change in deaf children to be able to socialize and interact with the surrounding community who are not deaf. the environment can also motivate children with hearing impairment to take part in skills training activities, talents and interests. A supportive environment, makes deaf children feel comfortable, safe and accepted by society. Thus the deaf child feels given the opportunity to appear, to do the same as other normal children. An opportunity that was rarely given to a deaf child before. With the opportunities that have been given, children with hearing impairment feel motivated to do something that can make works that can be appreciated by the wider community. The selfconfidence that emerges can turn a deaf child who was previously helpless into helplessness. Talent skills training and an interest in creative economybased empowerment are assisted by trainers who are professional in their fields.

Seventh, knowledge. The changes that occur during the communication process are cognitive. Namely changes in knowledge, understanding obtained by communicants after communicating with actors. Knowledge will add insight after the communicant receives a lot of information conveyed by the actor or communicator (Kruijver et al., 2000; Rohrmann, 1992; Winefield \& Chur-Hansen, 2000). Empowerment of the creative economy becomes an entry point for inviting deaf children to have the ability and empowerment and to be economically independent. Based on the talents and abilities possessed by each deaf person, provided with training and mentoring both in theory and practice.

Henceforth, their religious knowledge is also provided as provisions for carrying out their obligations as Muslims. So far they have very little 
understanding of religious knowledge and practices, and do not know the procedures for carrying out worship. Not only ignorance and incomprehension of deaf children towards religious teachings and religious guidance, but the process of religion has not been fully felt by deaf children. All this time, deaf children need a thorough and comprehensive religious learning process. Deaf children need help in terms of religion and understanding religious teachings.

Eighth, behavior. The communication process not only changes the knowledge of the communicant, but also changes attitudes and behavior (Hartmann et al., 2012; Valente et al., 1998). Empowerment is the process of making objects/ targets capable or empowered (Hennestad, 1998). Empowered means being able to increase dignity and get out of dependence that is a trap of poverty and underdevelopment (Abelev, 2009). Coaching has the aim of exploring and discovering the strengths or potential of the deaf group. Coaching to get what is the strength and potential of the deaf. After coaching it is continued with mentoring. Assistance is an effort to develop the potential or strengths that children with hearing impairment already have in the long term and sustainably. With talents that children with hearing impairment continue to develop have produced innovative product.

Increasing ability in the economic field further increases the confidence of deaf children when they are around (Pratiwi \& Laksmiwati, 2016). After gaining self-confidence they feel comfortable and safe in the midst of such a different environment for deaf children. Thus deaf children can make decisions from all the actions they do, no longer do everything according to the decisions of others. Henceforth they are independent in fulfilling the necessities of life, including in carrying out religious practices, and have a high responsibility for what they do.

After participating in a creative economy-based empowerment process by carrying out activities for skills, talents and interests, in which there are also religious development activities. Deaf children experience changes in behavior, deaf children understand much more about their duties and obligations as creatures of Allah SWT. As a Muslim, a deaf child becomes a person closer to Allah SWT by continuing to carry out obligations, such as praying five times a day and returning to his nature as a born human. Deaf children understand better what heaven and hell are, deaf children better understand religious commands that they have not understood and understood. 
By drawing or painting, Beni, a deaf child, is able to generate income to meet the needs of his daily life and make Beni a human being who carries out his obligations as a good Muslim. By making batik, Arum can prove to others that with the work of children with hearing impairment they can inspire others. With salon skills, Cahyadi was able to return to being a man who had been his nature from birth. By dancing, Revinda is able to prove that limitations are not an excuse to stop learning, what is the ability of normal people, children with disabilities are also able to do it. By making coffee, Ravi and several other deaf children can also open their own business. Deaf children are able to produce coffers of income to meet their own needs and they are even able to open jobs for others.

With empowerment based on creative economy through talent skills and interest in making coffee (barista), deaf children are able to open a sign coffee shop. A coffee shop where all employees are deaf children. Thanks to the innovations made by deaf children, the signal coffee shop has also been named the first and only coffee shop in Pringsewu Regency and Lampung Province which is managed by people with disabilities, especially deaf children. One of the innovations in sign coffee shops is to have the concept of "drinking coffee while learning sign language." In the coffee shop business, the signal deserves to be side by side and even compete with coffee shops in Pringsewu Regency. What is sold in coffee shops is a sign that the deaf child does not have a deficiency or "disability". Superior products, as well as selected menus remain the taste of choice for coffee lovers. innovations created not only through menus that are different from other coffee shops, but also from shop buildings and the buying and selling process that uses sign language. In other words, in a sign coffee shop, not only economic activities are running, but educational activities, especially the socialization of the use of sign language.

Community empowerment can provide news and information to the scholars, preachers, ustadz and ustadzah to be able to provide Qur'an lessons using sign language and give da'wah by using sign language too. Or you can use a sign language interpreter so that the message can reach the deaf child. And these changes are not only felt by the deaf child himself, but also by the parents, family, friends and even the environment around the deaf child. Islamic community empowerment has a positive impact for the life of deaf children.

The persuasive da'wah process through empowerment of the deaf community can be described as follows: 


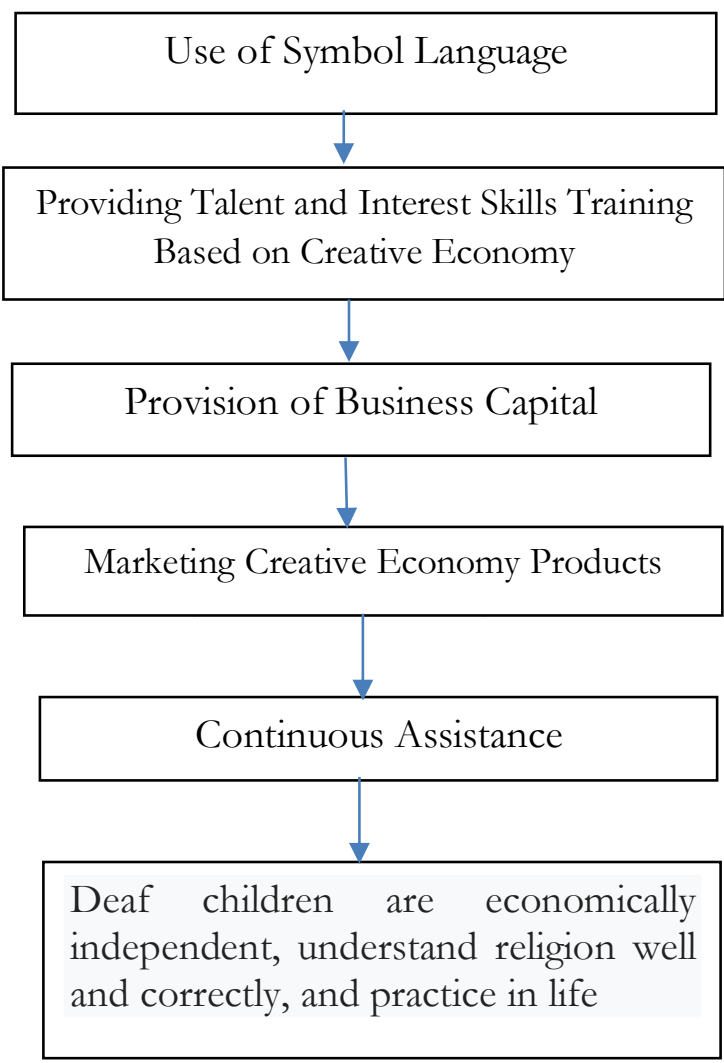

Figure 6. Islamic Community Empowerment Strategy Based on Creative Economy.

Based on the table above, it can be concluded that the persuasive communication process is complex. Starting from the use of sign language to the expected changes in attitude and behavior. To borrow the terms used by (Caroline \& Yohana, 2018), the persuasive communication process above uses the cognition and affection approaches. First, perusassive communication with a cognitive approach, meaning that established communication tries to provide religious understanding so that spiritual awareness is expected to emerge among the deaf community. The second approach is affection or emotional, namely by providing intense accompaniment and nurturing, so that the deaf community get social support and are able to build independence. 


\section{CONCLUSION}

Islamic community empowerment needs to pay attention to unique deaf characteristics, which are special and different from other normal children. So that the process of empowering the Islamic community cannot be equated. An innovative Islamic community empowerment model that is suitable to be applied and used in deaf children with a creative economy empowerment approach. Empowerment of the creative economy has two functions at once. first, empower them economically. Second, to become an entry point for deaf people to learn good religion, which is religious ceremonial, as well as to learn the spirit and substance of Islamic teachings from everyday life.

The findings above can be used as a reference material for community propagation and community empowerment activists, especially preaching and empowerment aimed at people with disabilities. The goal is that the preaching of Islam can touch more elements and dimensions of community life. Besides that, the concept of da'i who are able to speak sign language needs to be improved and reproduced, because seeing empirical facts, many deaf people are enthusiastic about studying religion, but are constrained by communication.

\section{REFERENCES}

Abelev, M. S. (2009). Advancing out of poverty: Social class worldview and its relation to resilience. Journal of Adolescent Research, 24(1), 114-141. https://doi.org/10.1177/0743558408328441

Amalia, S. (2019). Perancangan Animasi 2D Sebagai Media Edukasi Tentang Menumbuhkan Rasa Percaya Diri Untuk Remaja Tunarungu. Wimba : Jurnal Komunikasi Visual, 10(2), 107-120. https://doi.org/10.5614/jkvw.2019.10.2.4

Andersen, K., \& Clevenger, T. (1963). A Summary of Experimental Research in Ethos. Communication Monographs, 30(2), 59-78. https://doi.org/10.1080/03637756309375361

Azizah, L. F. (2010). Pengaruh Penerapan Metode Pembelajaran Snowball Throwing Terhadap Peningkatan Prestasi Belajar Matematika Siswa Tunarungu Ditinjau Dari Efikasi Diri Akademik. Jurnal Autentik, 2(1), 46-56.

Bretherton, I., McNew, S., \& Beeghly-Smith, M. (1981). Early person knowledge as Expressed in Gestural and Verbal Communication: When do Infants Acquire A "Theory of Mind"? Story completion 
task coding system View project. Social Cognition in Infancy, January 1981 ,

https://www.researchgate.net/publication/280311242

Buchan, N. R., Johnson, E. J., \& Croson, R. T. A. (2006). Let's get personal: An international examination of the influence of communication, culture and social distance on other regarding preferences. Journal of Economic Behavior and Organization, 60(3), 373-398. https://doi.org/10.1016/j.jebo.2004.03.017

Burns, T. W., Connor, D. J. O., \& Stocklmayer, S. M. (2003). Science communication: a contemporary definition. Public Understanding of Science, 12(2), 183-202. https://doi.org/10.1177/09636625030122004

Caroline, A., \& Yohana, N. (2018). Komunikasi persuasif komunitas kongkow nulis dalam meningkatkan budaya menulis di kalangan mahasiswa kota pekanbaru. JOM FISIP, 5(1), 1-13.

Damian, D., Izquierdo, L., Singer, J., \& Kwan, I. (2007). Awareness in the wild: Why communication breakdowns occur. Proceedings - International Conference on Global Software Engineering, ICGSE 2007, 81-90. https://doi.org/10.1109/ICGSE.2007.13

Fitriawan, R. (2016). Peningkatan Keterampilan Vokasional Melalui Pelatihan Cetak Sablon Kaos Bagi Anak Tunarungu Kelas Xii Di Slb Bakti Putra Ngawis. Jurnal Widia Ortodidaktika, 5(9), 895-907.

Hartmann, M., Gilles, K., Shattuck, D., Kerner, B., \& Guest, G. (2012). Changes in couples' communication as a result of a male-involvement family planning intervention. Journal of Health Communication, 17(7), 802-819. https://doi.org/10.1080/10810730.2011.650825

Hennestad, B. W. (1998). Empowering by de-depowering: Towards an HR strategy for realizing the power of empowerment. International Journal of Human Resource Management, 9(5), 934-953. https://doi.org/10.1080/095851998340883

Hidayaturrahman, M. (2018). Analisis Curse Theory pada Sumber Daya Alam Migas Bagi Warga Madura. Jurnal Studi Agama Dan Masyarakat, 14(1), 12. https://doi.org/10.23971/jsam.v14i1.774

Hidayaturrahman, M., Hidayat, I., \& Wibisono, A. (2020). Why Development Failed? Facts and Analysis of Development Failure in Sumenep. Jurnal Ekonomi Pembangunan, 18(01), 17-38.

Hovland, C. I., \& Weiss, W. (1951). The influence of source credibility on communication effectiveness. Public Opinion Quarterly, 15(4), 635-650. 
https://doi.org/10.1086/266350

Koeswantono, S. (2017). Pemberdayaan masyarakat melalui pelatihan menyulam pada ibu-ibu di desa pabuaran kecamatan sukamakmur kabupaten bogor. Jurnal Sarwahita, 11(2), 82-86.

Kruijver, I. P. M., Kerkstra, A., Francke, A. L., Bensing, J. M., \& Van De Wiel, H. B. M. (2000). Evaluation of communication training programs in nursing care: A review of the literature. Patient Education and Counseling, 39(1), 129-145. https://doi.org/10.1016/S07383991(99)00096-8

Kurniasari, Y., Suseta, B., Hendiyani, N., \& Abadi, A. M. (2020). Classification of Open Unemployment Rate in Indonesia with Mamdani Fuzzy Inference System. Journal of Physics: Conference Series, 1581(1), 0-8. https://doi.org/10.1088/1742-6596/1581/1/012010

Kurniawati, D. (2013). Pemberdayaan Masyarakat Di Bidang Usaha Ekonomi (Studi Pada Badan Pemberdayaan Masyarakat Kota Mojokerto). Jurnal Administrasi Publik. Mahasiswa Universitas Brawijaya, 1(4), 9-14.

Light, J., \& McNaughton, D. (2014). Communicative competence for individuals who require augmentative and alternative communication: A new definition for a new era of communication? AAC: Augmentative and Alternative Communication, 30(1), 1-18. https://doi.org/10.3109/07434618.2014.885080

Linda, R. (2018). Pemberdayaan Ekonomi Kreatif Melalui Daur Ulang Sampah Plastik (Studi Kasus Bank Sampah Berlian Kelurahan Tangkerang Labuai). Jurnal Al-Iqtishad, 12(1), 1. https:// doi.org/10.24014/jiq.v12i1.4442

Liu, H., \& Priest, S. (2009). Understanding public support for stem cell research: Media communication, interpersonal communication and trust in key actors. Public Understanding of Science, 18(6), 704-718. https://doi.org/10.1177/0963662508097625

Loula, A., Gudwin, R., El-Hani, C. N., \& Queiroz, J. (2010). Emergence of self-organized symbol-based communication in artificial creatures. Cognitive Systems Research, 11(2), 131-147. https://doi.org/10.1016/j.cogsys.2008.10.002

Mahmudah, U. (2018). Autoregressive Integrated Moving Average Model to Predict Graduate Unemployment in Indonesia. Practice and Theory in Systems of Education, 12(1), 43-50. https://doi.org/10.1515/ptse2017-0005 
Mayer, S., \& Musatti, T. (1992). Towards the use of symbol: Play with objects and communication with adults and peers in the second year. Infant Behavior and Development, 15(1), 1-13. https://doi.org/10.1016/0163-6383(92)90002-N

Mehrabian, A., \& Wiener, M. (1966). Non-immediacy between communicator and object of communication in a verbal message: Application to the inference of attitudes. Journal of Consulting Psychology, 30(5), 420-425. https://doi.org/10.1037/h0023813

Michael, P., Holbert, R. L., Zubric, S. J., Pasha, N. H., \& Lin, W.-K. (2014). Role and Influence of Communication Modality in the Process of Resistance to Persuasion. Media Psychology, 2(1), 1-33. https://doi.org/10.1207/S1532785XMEP0201

Mierrina. (2018). Intervensi religius islam bagi anak berkebutuhan khusus. Jurnal Bimbingan Dan Konseling Islam, 8(2), 187-207.

Muslim, A. (2017). Analisis Kegagalan Program Nasional Pemberdayaan Masyarakat dalam Membangun Kemandirian Masyarakat Miskin (Studi Kasus di Provinsi Daerah Istimewa Yogyakarta, Jawa Tengah, dan Jawa Timur). Jurnal Penyuluhan, 13(1), 79. https://doi.org/10.25015/penyuluhan.v13i1.14524

Pratiwi, I. D., \& Laksmiwati, H. (2016). Kepercayaan Diri dan Kemandirian Belajar Pada Siswa SMA Negeri "X" Iffa, Jurnal Psikologi Teori \& Terapan, 7(1), 43-49.

Putri, L. P., Bismala, L., \& Safina, L. (2019). Pemberdayaan ibu rumah tangga melalui pelatihan ekonomi kreatif sebagai upaya peningkatan kemandirian ekonomi. Jurnal Sains Penelitian \& Pengabdian, 2(19).

Ray, E. B., \& Miller, K. (1991). The influence of communication structure and social support on job stress and burnout. MCQ, 4(4), 506-527.

Revuelta, G. (2014). Impacts of science communication on publics, cities and actors. Journal of Science Communication, 13(1), 1-5. https://doi.org/10.22323/2.13010301

Rohrmann, B. (1992). The evaluation of risk communication effectiveness. Acta Psychologica, 81(2), 169-192. https://doi.org/10.1016/00016918(92)90004-W

Ruddle, R. A., Savage, J. C. D., \& Jones, D. M. (2002). Verbal communication during cooperative object manipulation. Proceedings of the 4th International Conference on Collaborative Virtual Environments, 120127. https://doi.org/10.1145/571878.571897

Sarry, S. M. (2018). Parental Emotional Coaching Untuk Meningkatkan 
Kemampuan Menghadapi Emosi Negatif Anak Tunarungu. Journal of Psychological Science and Profession, 2(2), 16-22. https://doi.org/10.24198/jpsp.v2i2.21193

Setyawan, D. (2017). Gerakan Intelektual Kolektif Komunitas\#Ayokedamraman dalam Pemberdayaan Warga Membangun Pariwisata Alam dan Ekonomi Kreatif. NIZHAM, 5(2), 15-28.

Stephenson, J., \& Linfoot, K. (1996). Intentional communication and graphic symbol use by students with severe intellectual disability. International Journal of Disability, Development and Education, 43(2), 147165. https://doi.org/10.1080/0156655960430205

Stevens, S. (1950). Introduction: A definition of communication. The Acoustical Journal of the Society of America, 22(6), 689-690.

Sulastri, S., \& Jati, R. P. (2016). Pembelajaran Pendidikan Agama Islam Siswa Tunarungu. Mudarrisa, Jurnal Kajian Kependidikan Islam, 8(1), $1-$ 30. https://doi.org/10.18326/mudarrisa.v8i1.1-29

Syafrudin, T., \& Sujarwo, S. (2019). Pengembangan Bahan Ajar Untuk Pembelajaran Matematika Bagi Siswa Tunarungu. Suska Journal of $\begin{array}{lll}\text { Mathematics } \quad \text { Education, } & \text { 5(2), }\end{array}$ https://doi.org/10.24014/sjme.v5i2.8170

Valente, T. W., Paredes, P., \& Poppe, P. R. (1998). Matching the message to the process: The relative ordering of knowledge, attitudes, and practices in behavior change research. Human Communication Research, 24(3), 366-385. 2 https://doi.org/10.1111/j.14682958.1998.tb00421.x

Watanabe, T., Okubo, M., Mutsuhiro, N., \& Danbara, R. (2010). InterActor: Speech-Driven Embodied Interactive Actor. International Journal, 17(1), 43-60. https://doi.org/10.1207/s15327590ijhc1701

Winefield, H. R., \& Chur-Hansen, A. (2000). Evaluating the outcome of communication skill teaching for entry-level medical students: Does knowledge of empathy increase? Medical Education, 34(2), 90-94. https://doi.org/10.1046/j.1365-2923.2000.00463.x 